\title{
THE BLINDING LIGHT: THE USES OF HISTORY IN CONSTITUTIONAL INTERPRETATION
}

\author{
JOHN G. WOFFORD $†$
}

1 HE past may be only prologue, but for the Supreme Court that prologue sometimes appears to direct the whole drama. The drama is the interpretation of the words of the United States Constitution. Even when the Court decides that history does not govern the case before it, as happened when the Court held that the equal protection clause forbids racially segregated public schools, ${ }^{1}$ the nine Justices were concerned enough about the past to have asked specifically for reargument on the question of the proper historical scope of the fourteenth amendment. ${ }^{2}$ However, so far as this writer can discover, there is no acceptable theory demonstrating why and how historical materials are relevant to the present resolution of present constitutional problems. Sometimes the Court indicates that historical materials are helpful, suggestive or illuminating - but not binding. Yet at other times the Court states flatly that history has conclusively resolved the problem. It is with this latter notion - that the past can bind the present in ways which extend beyond the words which the past has put in the Constitution-that this article is primarily concerned.

The past can be said to bind the present when a judge considers his own role to be that of discovering the intent of those who "framed" the document, of discovering the meaning which the words had at the time they were inserted in the document or of discovering the purpose for which particular propositions were designed. Separating any one of these three conceptions from the other two is a somewhat misleading undertaking, both because judges rarely distinguish between them, and because the investigatory tasks themselves-all presupposing that the solution is to be discovered-are closely connected. Nevertheless, the emphasis of each task is different. To search for intent is to look for a state of mind, either of "framer" or of "ratifier," which reveals past private notions about the proper scope and application of a constitutional provision. To search for meaning is to look for something seemingly more public and more tangible-something behind a word for which the word was said to stand as a sign. To search for purpose is to look neither for a

+ Member of the New York Bar and the District of Columbia Bar.

1 Brown v. Board of Educ., 347 U.S. 483, $489-90$ (1954).

2 Brown v. Boạrd of Educ., 345 U.S. 972 (1953). 
state of mind, nor for a widely accepted thing-behind-the-sign, but instead for a state of facts, a series of events, a concrete problem-in short, for the evil which the constitutional provision was designed to remedy. For purposes of analysis, therefore, each of these approaches may be examined separately.

\section{The SEARch for Intent}

Intent, if it is a state of mind, can be discovered only as it was expressed in words or actions. The words and actions usually considered most revealing of the intended scope of constitutional provisions are the debates and votes surrounding the drafting and ratifying of the Constitution and amendments. The theory behind consulting such sources, however, is rarely expressed. It should be closely examined, because the accuracy of the historical materials, especially those surrounding the drafting of the original document, and the assumptions behind the use of those materials are both highly questionable.

When Mr. Chief Justice Vinson was seeking "to demonstrate ... the true intent of the framers" of article III respecting the jurisdiction of the federal courts, he cited the rejection of various alternative proposals by the Philadelphia Convention in order to throw light upon the particular compromise reached. ${ }^{3}$ In a footnote the Chief Justice then declared: "The propriety of considering the proposals and debates of the Constitutional Convention was long ago considered by those most intimately concerned with its formulation." 4 One of "those most intimately concerned" was George Washington, whom the Chief Justice quoted as having referred the House of Representatives to "the Journals of the Great Convention" which the President had just deposited in the office of the Department of State. ${ }^{5}$ The other was James Madison, also cited by the Chief Justice for the propriety of consulting the Philadelphia proceedings. ${ }^{\circ}$ These references are significant because the original journal of

3 National Mut. Ins. Co. v. Tidewater Transfer Co., 337 U.S. 582, $631-33$ (1949) (dissenting opinion).

4 Id. at 631 n.8.

5 "If other proofs than these, and the plain letter of the Constitution itself, be necessary to ascertain the point under consideration, they may be found in the Journals of the Great Convention, which I have deposited in the office of the Department of State. In those Journals it will appear, that a proposition was made, 'that no Treaty should be binding on the United States which was not ratified by a law;' and that the proposition was explicitly rejected." President Washington, Message to the House of Representatives, March 30, 1796, in 5 ANNALS of Cong. 761 (1796).

6 The citation to Madison is not very persuasive. He merely commented upon Hamilton's opposition to resorting to extrinsic evidence by noting that Hamilton himself had advised, and probably drawn up, Washington's message supporting such a resort. "Whatever may be the degree of force in some of the remarks [of Hamilton], he pushes them too far," Madison wrote. The contradictions between the two view- 
the Convention and Madison's account of the debates are the two chief historical sources for our understanding of what happened behind the closed doors of the Philadelphia Convention. The accuracy of these two sources leaves a great deal to be desired.

Max Farrand, in the introduction to his compilation of all accounts of the Convention extant in $1911,{ }^{7}$ states that the official journal, apparently containing all motions and votes, was delivered to Washington, then president of the Congress of the Confederation, who in 1796 deposited the papers in the Department of State. There they remained, untouched, until Congress by joint resolution in 1818 ordered them printed. Farrand reports that President Monroe requested his Secretary of State, John Quincy Adams, to take charge of the publication:

The task proved to be a difficult one. The papers were, according to Adams, "no better than the daily minutes from which the regular journal ought to have been, but never was, made out." Adams reports that at his request William Jackson, the secretary of the Convention, called upon him and "looked over the papers, but he had no recollection of them which could remove the difficulties arising from their disorderly state, nor any papers to supply the deficiency of the missing papers." With the expenditure of considerable time and labor, and with the exercise of no little ingenuity, Adams was finally able to collate the whole to his satisfaction. General Bloomfield supplied him with several important documents from the papers of David Brearley; Charles Pinckney sent him a copy of the plan he "believed" to be one he presented to the Convention; Madison furnished the means of completing the records of the last four days ....8

As thus compiled, the Journal, Acts and Proceedings of the Convention... Which Formed the Constitution of the United States was printed in 1819. Adams felt that he there presented a "correct and tolerably clear view of the proceedings of the Convention . . . ."9 Farrand's own judgment, however, is more critical:

As Adams had nothing whatever to guide him in his work of

points of Hamilton, he continued, "are palpable." 9 Writings OF JAMES MAdison 240 (Hunt ed. 1910). Hamilton had written: "Nothing is more common than for laws to express and effect more or less than was intended." Id. at 241.

7 THE Records of the FEDERAL Convention of 1787 (Farrand ed. 1937) (hereinafter cited as FARRAND).

81 FARRAND xii.

9 Ibid. The Journal was reprinted in 1830 as volume 4 of the first edition of ElIIor, Debates in the Several State Conventions on the Adoption of the Federal Constrrution. In the second edition, 1836, and in all subsequent editions, it appears as volume 1. See 1 FarRand xii n.8. 
compilation and editing, mistakes were inevitable, and not a few of these were important .... With notes so carelessly kept, as were evidently those of the secretary, the Journal cannot be relied upon absolutely. The statement of questions is probably accurate in most cases, but the determination of those questions and in particular the votes upon them should be accepted somewhat tenatively. ${ }^{10}$

Material in addition to the Journal has, of course, been discovered; this enabled Farrand to speak of "mistakes" in the Journal itself. Most important are the notes which Madison made during the proceedings. Madison himself described how he made the notes, and how he then used them to reconstruct a more complete account:

I chose a seat in front of the presiding member, with the other members, on my right and left hand. In this favorable position for hearing all that passed I noted in terms legible and in abbreviations and marks intelligible to myself what was read from the Chair or spoken by the members; and losing not a moment unnecessarily between the adjournment and reassembling of the Convention I was enabled to write out my daily notes during the session or within a few finishing days after its close. ${ }^{11}$

Madison's notes were not published exactly as he had transcribed them after each session. For after the publication of the official-and inaccurate-Journal, Madison went over his notes and made numerous changes in them. According to Farrand, these emendations "seriously impaired the value of his notes," since many of the Journal's errors were simply duplicated. ${ }^{12}$

By 1911, when Farrand published all of the known records of the Convention, the Journal and Madison's Debates had been supplemented by other (and shorter) records made contemporaneously with the Convention and by statements made later by those who had been present. We know that other records once existed, although Farrand notes that it is "not probable ... that any such new material would modify to any great extent our conceptions of the Convention's work."13

In short, we have a picture of the Philadelphia proceedings, the various parts of which are generally consistent with each other. What we do not

$10 I d$. at xii-xiv.

11 Id. at xvi.

12 Id. at xvii. Madison's Debates were published in 1840, four years after his death. $I d$. at xv. They were then republished as volume 5 of Elliot's DeBAtes in 1845. See $i d$. at $\mathrm{xV}$ n.16.

13 Id. at xxiy. 
have, and indeed will never have, is any external check upon either the accuracy or the completeness of that picture. The conceptions of what occurred at Philadelphia remain, as Farrand put it, "ours."

If the Court's duty is to discover the best evidence of the states of mind of those who framed the Constitution at Philadelphia, then, despite the limitations upon our knowledge, ${ }^{14}$ we must be content with even an incomplete or inaccurate picture of the Philadelphia proceedings. But the model of a picture which from time to time may be corrected raises important questions which suggest that the Court's duty cannot be described quite so simply.

For one thing, if the accuracy of the evidence of intent improves with time, one might suppose that the older Court decisions, particularly those in the fifty years before the publication of Madison's Debates, ought to be considered less reliable as precedents than modern decisions made in the full light of the documentary evidence. But the Court has generally looked at the matter quite the other way: The older opinions are frequently given added value because many of the Justices during that period were personally familiar with the Philadelphia proceedings and thus were even closer to the real intent than later generations who could only glean it from printed records. In refusing to overrule a decision of Mr. Chief Justice Marshall, ${ }^{15}$ for instance, three Justices emphasized that Marshall "wrote from close personal knowledge of the Founders and the foundation of our constitutional structure"; 16 two others wrote that "Marshall had no mean share in securing adoption of the Constitution and took special interest in the Judiciary Article"; ${ }^{17}$ and two others wrote that one "well versed" in "the specific intent of the framers" on the subject of diversity jurisdiction, "writing for the Court within a few years of adoption of the Constitution," should be followed. ${ }^{18}$ Marshall's special reliability was stated somewhat more broadly by Charles A. Beard,

14 "But the perplexing paradox of all historical work is that what actually happened can never be recaptured, although historical research would lose its point without a belief that more of it can be recaptured than is presently known. . . . The happenings of history as contrasted with the reports about these happenings ... are devoured by time as soon as they happen. . . . If, then, all history is a gloss upon the happenings, in the form of reports and interpretations of reports . . . the intellectual standing of such a gloss becomes a problem." Friedrich, Law and History, 14 VAND. L. REv. 1027, 1031 (1961).

15 Hepburn \& Dundas v. Ellzey, 6 U.S. (2 Cranch) 445 (1805), which had held that the District of Columbia was not a "state" for purposes of the statute defining the jurisdiction of the lower federal courts.

16 Opinion of Jackson, J., joined bỷ Black and Burton, JJ., in National Mut. Ins. Co. v. Tidewater Transfer Co., 337 U.S. 582, 587 (1949).

17 Frankfurter, J., with Reed, J., dissenting, id. at 653.

18 Vinson, C.J., with Douglas, J., dissenting, id. at 645-46. 
in his investigation of the question: "Did the framers of the federal Constitution intend that the Supreme Court should pass upon the constitutionality of acts of Congress?"10 Beard gave Marshall's opinion in Marbury r. Madison ${ }^{20}$ special weight as evidence of just such an intent:

The great Justice who made the theory of judicial control operative had better opportunities than any student of history or law to-day to discover the intention of the framers of the federal Constitution. Marshall, to be sure, did not have before him Elliot's Debates, but he was of the generation that made the Constitution. He had been a soldier in the Revolutionary War. He had been a member of the Virginia convention that ratified the Constitution; and he must have remembered stating in that convention the doctrine of judicial control, apparently without arousing any protest. He was on intimate, if not always friendly, relations with the great men of his state who were instrumental in framing the Constitution. Washington once offered him the attorney-generalship. He was an envoy to France with two members of the convention, Charles Cotesworth Pinckney and Elbridge Gerry. He was a member of Congress for part of one term in Adam's administration; he was secretary of state under Adams; and he was everywhere regarded as a tower of strength to the Federalists. . . . It was, therefore, no closet philosopher, ignorant of the conditions under which the Constitution was established and unlearned in the reason and spirit of that instrument, who first enunciated from the supreme bench in unmistakable language the doctrine that judicial control over legislation was implied in the provisions of the federal Constitution. ${ }^{21}$

Despite Beard's rhetoric, he does have a point if we are really looking for the true state of mind of those who did the drafting: Marshall's judgment should be given special weight if he was well-acquainted with the drafters. But the notion of "the drafters" itself raises a further question: Which drafters? Surely some members of the Convention were more influential than others in the formulation of particular propositions and phrases, and presumably their intents are entitled to special weight. Beard endorses this approach by focusing his inquiry upon those among the Philadelphia delegates "whose judgment is entitled to respect":

There were in all fifty-five members of the Convention who were present at some of its meetings. Of these at least one-third took little or no part in the proceedings or were of little weight or were extensively absent. ... It is of course difficult to estimate the influence of the several members of the Convention, and

19 Beard, The Supreme Court and the Constitution 1 (1912).

205 U.S. (1 Cranch) 137 (1803).

21 BEARD, op. cit. supra note 19, at 113-15. 
between the extremes there are a few regarding whom there may reasonably be a difference of opinion.... Of the remaining members there were (say) twenty-five whose character, ability, diligence and regularity of attendance, separately or in combination, made them the dominant element in the Convention. 22

Beard then demonstrates that of these twenty-five with "character, ability, diligence and regularity of attendance, separately or in combination," seventeen at some time (not necessarily during the Philadelphia proceedings) recorded themselves in favor of judicial review.

Without quite so much head-counting, the Supreme Court has frequently made similar judgments about particular drafters whose opinions about the scope of certain sections are entitled to special weight. In considering the religious provisions of the first amendment, for instance, the Court quoted the letter in which Jefferson as President used the phrase "a wall of separation between church and State." The Court went on to declare: "Coming as this does from an acknowledged leader of the advocates of the measure, it may be accepted almost as an authoritative declaration of the scope and effect of the amendment thus secured."23

But if we are really searching for the states of mind of those responsible for the presence in the Constitution of a particular provision, it is hard to understand why we should be particularly concerned only with those who drafted the provision or supported it actively. Responsibility is more widely distributed; in order to become part of the Constitution, the provision had to be accepted by the Philadelphia Convention or by the Congress, and then ratified by the states acting either through legislatures or through special conventions.

In this sense, interpreting the Constitution is profoundly different from interpreting documents which result from the deliberations of fewer persons. A will purports to be the expressed intent of one person; a contract the expressed intent of two or more; and a statute the expressed intent of one or two deliberative bodies. The Constitution, however, purports to be the expressed intent of a widely dispersed and numerically large sovereign electorate: "We the People of the United States . . . do ordain and establish this Constitution." However mythical the notion of the People as Sovereign may be, it is not at all unrealistic to state that a large number of people were responsible for the Constitution as it emerged and as it was later, from time to time, amended. ${ }^{24}$

22 Id. at 16-17.

23 Reynolds v. United States, 98 U.S. 145, 164 (1878) (holding polygamy constitutionally punishable as a crime).

24 Mr. Justice Peckham made this important point when he compared the relevance of statements made in support of a statute with the relevance of statements made in 
Yet to admit the relevance of such a large number of states of mind is to set forth a task virtually impossible to fulfill. Joseph Story long ago pointed out that the varying interpretations of the Constitution presented in the state conventions make the debates in those conventions at best uncertain and inconclusive criteria. ${ }^{25}$ The delegates to the ratifying conventions were advocates, using every possible argument for either the support or rejection of the proposed Constitution. To what extent is the mental acceptance or rejection of such arguments relevant? Indeed, to what extent can such acceptance or rejection on the part of those who voted in all of the state ratifying conventions ever be discovered? Surely intent in this sense is both irrelevant and unrecorded.26

The essential point is that what was accepted at Philadelphia (or in Congress in the case of amendments) and later ratified was a group of words, not the intended interpretation of those words--whether expressed or unexpressed. Only the document itself bound the nation, both then and now. It is not only a "compliment" but a duty to believe that the framers "meant no more than they said" for, as Charles P. Curtis, Jr. has observed, only what they said was ratified.27 "If we look behind or beyond what they set down in the document, prying into what else they wrote and what they said, anything we may find is only advisory. They may sit in at our councils. There is no reason why we should eavesdrop on theirs." 28

support of an amendment to the Constitution. The latter statements he said, are "of less materiality than in that of an ordinary bill or resolution. A constitutional amendment must be agreed to, not only by Senators and Representatives, but it must be ratified by the legislatures, or by conventions, in three fourths of the States before such amendment can take effect." Maxwell v. Dow, 176 U.S. 581, 602 (1900). Madison had long before stated the same point more broadly: "It is the sense of the nation, therefore ... not the sense of the General Convention, that is to be consulted; and that sense, if not taken from the act itself, is to be taken from the proceedings of the State Conventions \& other public indications as the true keys to the sense of the Nation." Fleet, Madison's "Detached Memoranda," 3 WILllam \& MarX Q. Hist. Magazine (3d Ser.) 534, 544 (1946).

25 STORX, CoMmentaries on the Constitution 406 (1st ed. 1833).

20 Charles Beard admitted that "a sound rule of interpretation would compel us to ascertain the opinion of these bodies on the point at issue," but added that "a full examination of the materials on the state conventions, as anyone can see, would require years of research into the lives and opinions of several hundred members." BEARD, op. cit. supra note 19 , at 68 . Moreover, such a search might commit a modern court to the general attitudes of the state electorates in 1787-89, generally reflecting "substantial property interests," while "the property-less, who were disgruntled with the handiwork of the Philadelphia conference, could do nothing but gnash their teeth." Id. at 102. Surely the property qualifications upon the right to vote in 1787 should not be given a continuing impact through any binding force given to the states of mind of those who could then vote.

27 CURTIS, Lions Under the Throne 3 (1947).

$28 \mathrm{Id}$. at 2. The same point has rightly been made with regard to statutes. "The 
The intent of the framers-or indeed of the ratifiers-is not binding for yet another reason. In most litigation raising issues of constitutional interpretation, the problem is not to apply one constitutional principle but to reconcile two or more such principles. The nature of the intent behind any one principle will therefore almost by definition not resolve a problem arising from the clash of two principles, since the two intents are themselves likely to clash. Curtis has again put the point with special clarity: Judges, he said, "are engaged in doing something, not looking for anything. ... The judicial process is a part of the operation by which the law is fitted into the rest of law and thus put into effect."29

One point follows directly from this conception of the judicial process: The particular issue in the litigation, presupposing a clash of conflicting principles, necessarily arises at a later time than the original formulation of those principles. The formulation binds the future; but it is the task of the future to resolve the conflict. In other words, even had the Constitution been enunciated by a single great Law-Giver, his private intentions as to its scope could almost never resolve the problem before the Court, because the particular problem had simply not then arisen. To search for the intent of the Law-Giver in such a case is to search for something that never existed. When Marshall uttered his famous warning that "we must never forget, that it is a constitution we are expounding," 30 he was essentially stating that, within the contours of the document, the future must be left free to solve its problems, because that is what is implied by the word "constitution." The Constitution, he declared was "intended to endure for ages to come, and, consequently, to be adapted to the various crises of human affairs. ... It would have been an unwise attempt to provide, by immutable rules, for exigencies which, if foreseen at all, must have been seen dimly, and which can be best provided for as they occur." 31

Marshall's language is here highly significant. The Constitution was intended to endure and to be adapted. Even if the task of the Court were to search for the intent of the framers, the framers' two most basic

Rules of the House and Senate, with the sanction of the Constitution, require three readings of an Act in each House before final enactment. That is intended, I take it, to make sure that each House knows what it is passing and passes what it wants, and that what is enacted was formally reduced to writing. It is the business of Congress to sum up its own debates in its legislation. Moreover, it is only the words of the bill that have presidential approval, where that approval is given. It is not to be supposed that in signing a bill the President endorses the whole Congressional Record." Jackson, J., concurring in Schwegmann Bros. v. Calvert Distillers Corp., 341 U.S. 384, 396 (1951). And see Taney, C.J., in Aldridge v. Williams, 44 U.S. (3 How.) 1,24 (1845).

29 Curtis, op. cit. supra note 27, at 7.

30 McCulloch v. Maryland, 17 U.S. (4 Wheat.) 316, 407 (1819).

81 Id. at 415. 
intents surely were to express themselves as clearly as they could on all points on which they could agree, ${ }^{32}$ and to make only the written expression of such agreement binding upon the future. Paradoxically, an intended clarity in expression and an intended flexibility in application frees the future from the force of any narrower intents.

\section{The Seargh for Meaning}

Even if the states of mind of the framers of the Constitution are not binding unless expressed in the document, the words they did use in that document had meanings in 1787 , and those meanings are sometimes considered a part of the document, just as if the words used were there elucidated and defined. ${ }^{33} \mathrm{~A}$ search for meaning-that stuff behind the words for which the words stand as signs-sounds like a search for something more solid and more fixed than intent.

What does this stuff called meaning look like? This, of course, is a profoundly difficult philosophical question. In one sense, meaning is a state of mind-the thoughts which a person using a word had at the time he used it. A state of mind, however, is private, and since we are speaking about language, and since the purpose of language is communication, private states of mind will not suffice. Meaning must have been communicated from one person to another.

The meaning of some words can be communicated by pointing to an

32 At times in the Philadelphia proceedings, the delegates, unable to agree upon a particular principle, seem to have chosen words which deliberately left the matter unsettled. See BEARD, op. cit. supra note 19, at 65. Baldwin, a member of the Convention from Georgia, made the point a broad one: "He said it was not to disparage the instrument, to say that it had not definitely, and with precision, absolutely settled everything on which it had spoken. He had sufficient evidence to satisfy his own mind that it was not supposed by the makers of it at the time but that some subjects were left a little ambiguous and uncertain." $I d$. at 66 . Curtis has echoed this point: "The fact is, when we come upon an ambiguity, we must take it to be deliberate." CuRTIs, op. cit. supra note 27, at 3. This notion that certain constitutional provisions were intended to be ambiguous suggests that other provisions were not so intended. Since we can never know which were and which were not so intended, it seems impossible to try to separate constitutional provisions into one category or the other. And the idea that the Convention deliberately adopted ambiguous provisions is probably somewhat fictional, since, as Madison said, that Convention framed the Constitution "with so much deliberation, and with so manifest a purpose of specifying its objects, and defining its boundaries." Madison, Letter to Peter S. Duponceau, August 1824, in 9 Writings of James Madison 198, 199 (Hunt ed. 1910).

33 The Constitution "must be construed now as it was understood at the time of its adoption. It is not only the same in words, but the same in meaning . . . . Any other rule of construction would abrogate the judicial character of this court, and make it the mere reflex of the popular opinion or passion of the day. This court was not created by the Constitution for such purposes." Taney, C.J., in Dred Scott v. Sandford, 60 U.S. (19 How.) 393, 426 (1857) (holding a Negro slave could not become a citizen of a state for purposes of federal court diversity jurisdiction). 
object, like a table or a chair. This is what philosophers call "ostensive definition." But very few words have meaning in this rather primitive sense. And even with respect to those few there are difficulties, since the person trying to learn the meaning of the word must understand what kind of "thing" is being pointed to-What is it that makes this a table? Its shape? Its color? Its smell? What if the person does not know what is meant by "color"? It is impossible to point to the concept "color."

Since few words can be defined ostensively, and since even when they can be so defined the surrounding words must already be understood, many philosophers have come to say that for most words their meaning is their use. ${ }^{34}$ The use is understood because other people seem to use

34 See Wrttenstern, Philosophical Investigations pt. I, § 43 (Anscombe trans. 1958). See generally $i d$. at $\S \S 1-71$. To say that meaning is "use" does not dispose of all problems of definition, because our language rightly permits us to say that particular uses are more correct or less correct, precise or imprecise, generally accepted or questionable. "Where we can speak of managing, handling and employing we can speak of mismanaging, mishandling and misemploying. There are rules to keep or break, codes to observe or flout. Learning to use expressions, like learning to use coins, stamps, cheques and hockey-sticks, involves learning to do certain things with them and not with others; when to do certain things with them, and when not to do them." Ryle, Ordinary Language, 62 Philosophucal Review 167, 173 (1953). "Meaning" is probably more accurately defined as the rules which regulate the use of a word, Butchvarov, Meaning-as-Use and Meaning-as-Correspondence, 35 PHLosophy 314 (1960); indeed, meaning is only one of the rules governing the use of a word-other rules deal with grammar, pronunciation, punctuation, etc. Brown, Meaning and Rules of Use, 71 Mrnd 494 (1962). Despite these limitations to the idea that meaning is use, the contribution of the "linguistic philosophers" has been to demonstrate that the rules of use (and of meaning) change over time; that there is no hard and fast definition clinging inescapably and mysteriously to any one word; and that words are only understandable in their contexts. "The slogan 'Don't ask for the meaning, ask for the use' warns us to stop asking 'What is the analysis (the meaning) of this statement?' expecting to find some equivalent statement, complying probably with some preconceived requirements, and being dissatisfied if we fail; instead we are to ask what is done by the use of the statement." URMson, Philosophical ANalysis: ITs Development Between the Two World Wars 179 (1956). Although the word "use" itself can be somewhat ambiguous, the "fluidity of word-uses" is an essential assumption about language, since "an important part of what people call 'getting the feel of' a language is acquiring the ability to adapt it intelligibly to our constantly changing needs and situations." Cohen, On the Use of "the Use of," 30 Phrlosophy 7, 11-12 (1955). In trying to understand the meanings of words, we are therefore faced with factors suggesting change and factors suggesting continuity. On the one hand, communication presupposes a basic continuity: "[I]t is no accident that ways of employing words, as of employing coins, stamps, and chessmen, tend to be identical through a whole community and over a long stretch of time. We want to understand and be understood; and we learn our native tongue from our elders. Even without the pressure of legislation and dictionaries, our vocabulary tends towards uniformity. Fads and idiosyncracies in these matters impair communication." Ryle, supra at 177. (emphasis in original.) On the other hand, words do change in meaning over time, and criteria for establishing identity of meaning can never be completely reliable. HAMPShIRE, Thought ANd Acrron 11-67 (1959). See generally Ogden \& RICHARds, The MEANing of Meaning (1956). To suggest that meaning is use is thus to stress the difficulties of communication and the fallibility of definitions, particularly over time. 
the same word in the same way when speaking of roughly the same subjects with roughly the same purpose. A dictionary is thus only a collection of common uses, and these uses are found generally in propositions and sentences. Rarely is a word used alone, and even when it is-like "Yes" or "Whew!"-its meaning can only be understood by its connection with what has gone before or by the facial expression or tone of voice of the speaker. In this sense, a word never has a meaning isolated from its context: The proper focus of attention is always upon words in clusters and upon clusters in particular applications.

If the meaning of a word is its use, then our question must be whether the various uses to which a constitutional word was put in 1787-or at some later time in the case of amendments-are limitations upon the uses to which courts today can put the same words. Are we limited to past uses?

In order to approach this question, we must first decide where we should go to discover a past use. The accounts of the Philadelphia proceedings can help to set the words in context, but as noted in the discussion of intent, those accounts are not necessarily accurate, and that context is not what was ratified by the state conventions. Indeed, the existence of ratification as a device to spread responsibility forces us to look for "common meanings"-common uses for words at that time. Yet no American dictionary existed at the time the Constitution was drafted; Noah Webster's, the first, was not published until 1828. Roughly contemporaneous writings may be consulted, but there lurks in every such comparison the further question of whether the word was used in the same way in the two documents. The Federalist Papers, for instance, have often been considered an appropriate place in which to discover past uses, ${ }^{35}$ but those writings were calculated to put forth persuasive interpretations of the Constitution itself; whether The Federalist's interpretations were accepted or rejected in the process of ratification is obviously an unanswerable question. If a writing designed to persuade on the very question of appropriate uses is therefore peculiarly suspect, a writing of more independent significance, such as the Declaration of Independence, is also not very helpful-precisely because it is a different document in a different context. Our standards of sameness and difference are inherently modern; we can never know with certainty whether or not words in two different documents were used in the same way, and we thus follow use after use after use in an unending circle.

Courts frequently attempt to escape from this circle by comparing words with the way people acted at the time the words were used. Thus

$35 \mathrm{Mr}$. Chief Justice Marshall endorsed The Feneralist PApERs for this purpose in Cohens v. Virginia, 19 U.S. (6 Wheat.) 264, $418-19$ (1821). 
the Dred Scott Court compared the very general words of the Declaration of Independence and of the Constitution with the existence of slavery as a fact, and concluded that for purposes of diversity jurisdiction the word "citizen" did not include a slave. ${ }^{36}$ Yet surely Abraham Lincoln's answer to this "practical construction" is convincing: A proposition in a constitution is an ideal, and merely because people in practice failed to achieve the ideal is no reason to make those past failures binding upon the present. ${ }^{37}$ By the same token, practical construction after the enactment of the Constitution can never show that the practice was necessarily sanctioned by the documents, even if that practice was not challenged. ${ }^{38} \mathrm{~A}$ comparison of constitutional words with the concrete actions of people, either before or after those words were in effect, therefore provides no greater certainty as to the proper meanings of those words than does a comparison with other writings. Actions, in these situations, do not speak louder than words.

Even if we can never know with certainty how a constitutional word was used in 1787, we can probably discern past uses for some such words with greater clarity than for others. And if the Court is to be bound by such past uses, an approximation must be better than nothing. But how

36 Dred Scott v. Sandford, 60 U.S. (19 How.) 393, 409-10 (1857).

37 Lincoln said: "I think the authors of that notable instrument intended to include all men .... They did not mean to assert the obvious untruth, that all were then actually enjoying that equality, nor yet, that they were about to confer it immediately upon them .... They meant simply to declare the right, so that the enforcement of it might follow as fast as circumstances should permit. They meant to set up a standard maxim for free saciety, which could be familiar to all, and revered by all; constantly looked to, constantly labored for, and even though never perfectly attained, constantly approximated, and thereby constantly spreading and deepening its influence, and augmenting the happiness and value of life to all people of all colors everywhere. The assertion that 'all men are created equal' was of no practical use in effecting our separation from Great Britain; and it was placed in the Declaration, not for that, but for future use." Lincoln, Speech at Springfield, Ill., June 26, 1857, in Abraham Lincoln: His Speeches and Writings, 352, 360-61 (Basler ed. 1946).

38 As Jefferson said, rebutting the argument that the Virginia form of government, passed as an ordinary act of the assembly, could be considered a constitution merely because it had been treated as such by the assembly: "But, say they, the people have acquiesced, and this has given it an authority superior to the laws. It is true that the people did not rebel against it: and was that a time for the people to rise in rebellion? Should a prudent acquiescence, at a critical time, be construed into a confirmation of every illegal thing done during that period? . . . But to what dangerous lengths will this argument lead? Did the acquiescence of the colonies under the various acts of power exercised by Great Britain in our infant state, confirm these acts, and so far invest them with the authority of the people as to render them unalterable, and our present resistance wrong? On every unauthoritative exercise of power by the legislature must the people rise in rebellion, or their silence be construed into a surrender of that power to them? If so, how many rebellions should we have had already? One certainly for every session of assembly." JefFerson, Notes on Virginia, Query XIII, § 5, obj. 3 (1782), in 4 WORKS OF ThOMAS JEFFERSON 27-28 (Fed. ed. 1904). 
do we know when we have come upon one of those words used in 1787 with this special clarity?

It is sometimes said that there are two kinds of words in the Constitution-big words having many uses and small words having fewer uses. ${ }^{39}$ Presumably on the theory that many uses are harder to find than fewer uses, the big words have come to be called broad, general, imprecise or vague, while the small are called specific, technical, precise or concrete. Mr. Justice Frankfurter was fond of asserting this dichotomy. In placing a "bill of attainder" in the "specific" category, he wrote:

Broadly speaking, two types of constitutional claims come before this Court. Most constitutional issues derive from the broad standards of fairness written into the Constitution (e.g., "due process," "equal protection of the laws," "just compensation"), and the division of power as between States and Nation. Such questions, by their very nature, allow a relatively wide play for individual legal judgment. The other class gives no such scope. For this second class of constitutional issues derives from very specific provisions of the Constitution. These had their source in definite grievances and led the Fathers to proscribe against recurrence of their experience. These specific grievances and the safeguards against their recurrence were not defined by the Constitution. They were defined by history. Their meaning was so settled by history that definition was superfluous. Judicial enforcement of the Constitution must respect these historic limits. ${ }^{40}$

His conclusion-that "enforcement" of the Constitution must respect the "historic limits" of these specific words-will be examined shortly; at this point, we should merely note that the difference between the "broad" words and the "specific" words is not elucidated beyond the assertion that history defines the latter.

That it may not be easy to agree upon the proper category is indicated by the fact that while Mr. Justice Frankfurter considered the privilege against self-incrimination one of the specific provisions of the Constitution, Judge Learned Hand considered it one of the broad. Frankfurter

39 "Just as the framers of the Constitution often chose not to express their own thoughts at all on some questions, preferring to leave the question unanswered and open for possibly better men with surely more information, so also they chose their words for size, for length. Sometimes a big word with many applications . . . sometimes a smaller word when they wanted to be more specific, nearer the concrete." CuRTss, op. cit. supra note 27, at 20.

40 United States v. Lovett, 328 U.S. 303, 321 (1946) (concurring opinion). For support of the view that history is particularly relevant to certain constitutional provisions and less relevant to others, see Weiner, Uses and Abuses of Legal History: A PractiTIONER'S VIEW 16-25 (Selden Society Lecture 1962). 
wrote of the privilege: "We are not dealing here with one of the vague, undefinable, admonitory provisions of the Constitution whose scope is inevitably addressed to changing circumstances. The privilege against self-incrimination is a specific provision of which it is peculiarly true that 'a page of history is worth a volume of logic." "41 In strikingly similar language, Hand also set up two categories, but placed the first, fifth and fourteenth amendments, presumably in their entireties-in the broad category, since they are "cast ... in such sweeping terms that their history does not elucidate their contents." 42 Such provisions are "admonitory or hortatory," he said, "not definite enough to be guides on concrete occasions ...." ${ }^{43}$ Whether a word is broad or specific is thus a matter for dispute.

Mr. Justice Frankfurter was apt to resolve such a dispute by reference to the subject matter of the disputed provision. He usually placed phrases dealing with the scope of the federal judiciary, for instance, in the specific category. Thus when the Court had to decide whether the District of Columbia could be a "State" for purposes of diversity jurisdiction, he declared that the framers, "in making provision in regard to 'States,' meant the States which sent them as delegates to the Philadelphia Convention and the States which were to be admitted later." 44 The District of Columbia could not become such a "State." Why did "State" simply mean State in the judiciary article, while in the fourteenth amendment for purposes of State action it is much more broadly construed? "The very subject matter of sections 1 and 2 of article III," the Justice said, "is technical in the esteemed sense of that term. These sections do not deal with generalities expanding with experience. Provisions for the organization of courts and their jurisdiction presuppose definiteness and precision of phrasing." 45 The legal competence of the drafters of article III was reflected in the precise enumeration of the heads of jurisdiction, and that enumeration, he said, "ought to preclude the notion that they shared the latitudinarian attitude of Alice in Wonderland toward language." 46

41 Ullman v. United States, 350 U.S. 422,438 (1956) (holding constitutional a federal statute granting immunity from prosecution based on self-incriminatory testimony before a grand jury). (Emphasis added.).

42 HaNd, The Bill of Righrs 30 (1960).

43 Id. at 34. (Emphasis added.).

44 National Mut. Ins. Co. v. Tidewater Transfer Co., 337 U.S. 582, 653 (1949) (dissenting opinion).

$45 I d$. at 645. (Emphasis added.).

46 Ibid. Mr. Justice Frankfurter had made the same distinction between generalities which expand, and technical terms which do not, in declaring that Congress could not use its article $I$ power over the District of Columbia to enlarge the power of article III federal courts: "No provisions of the Constitution, barring only those that draw on arithmetic, as in prescribing the qualifying age for a President and members 
It is not at all clear, however, whether Mr. Justice Frankfurter placed a particular word in the frozen category because the word was specific or whether he called it specific-or "technical in the esteemed sense of that term"-because he wanted it to be frozen. Mr. Justice Rutledge, in the same case, put the word "State" in the non-frozen category quite apparently because he thought it important to do so: "Key words like 'state,' 'citizen,' and 'person' do not always and invariably mean the same thing," he said, and an expanding scope should be permitted to those clauses "affecting civil rights of citizens," such as the right to sue in a federal district court. 47 Rutledge seems to admit that "State" in 1787 meant State, but refused to be bound by that meaning. Are constitutional words simply "frozen" or "dynamic" as the individual judge sees fit?

Perhaps it is the dichotomy which is at fault. If past uses are binding upon the present simply because they existed in 1787, then surely it is misleading to put the words into two categories-one of which contains words which had precise meanings in 1787, and the other of which contains words which were used so imprecisely that history can be of no help in elucidating their meanings. The historical evidence is simply not of such an all-or-nothing kind. On the one hand, while a phrase like "full faith and credit" sounds very technical, Mr. Justice Jackson concluded that history could help very little in elucidating the term, since the common law on which the concept seems to have been built was unclear, and since there is no satisfactory evidence that members of the Constitutional Convention "had more than a hazy knowledge of the problems they sought to settle or of those which they created" by putting

of a Congress or the length of their tenure of office, are more explicit and specific than those pertaining to courts established under Article III. 'The judicial power' which is 'vested' in these tribunals and the safeguards under which their judges function are enumerated with particularity. Their tenure and compensation, the controversies which may be brought before them, and the distribution of original and appellate jurisdiction among these tribunals are defined and circumscribed, not left at large by vague and elastic phrasing. The precision which characterizes these portions of Article III is in striking contrast to the imprecision of so many other provisions of the Constitution dealing with other very vital aspects of government. This was not due to chance or ineptitude on the part of the Framers. The difference in subject-matter account for the drastic differences in treatment. Great concepts like 'Commerce .. . among the several States,' 'due process of law,' 'liberty,' 'property' were purposely left to gather meaning from experience. For they relate to the whole domain of social and economic fact, and the statesmen who founded this Nation knew too well that only a stagnant society remains unchanged. But when the Constitution in turn gives strict definition of power or specific limitations upon it we cannot extend the definition or remove the translation. Precisely because it is a constitution we are expounding, M'Culloch v. Maryland . . . we ought not to take liberties with it." Id. at 646-47.

47 Id. at 623 (for himself and Murphy, J.). Mr. Justice Rutledge had said: "[O]ur Constitution today would be very different from what it is if such a narrow and literal construction of each of its terms had been transmuted into an inflexible rule of constitutional interpretation." Id. at 620 . 
the phrase in the Constitution. ${ }^{48}$ But Mr. Justice Jackson's own study assumed that history could be of some help. On the other hand, a "big word" like "due process" has had past uses the outlines of which can be roughly discerned. ${ }^{49} \mathrm{Mr}$. Justice Frankfurter himself frequently examined the state of affairs at the time the fourteenth amendment was enacted in order to ascertain the meaning of "due process" in deciding how far the strictures of the Bill of Rights apply to the states. ${ }^{50}$ If past uses are binding upon the present merely because the words were inserted in a formal document, ${ }^{51}$ surely all such past uses are equally binding for all the words.

But to say that past uses should be equally binding for all constitutional words is not to admit that past uses are binding at all. Indeed, it is frequently not clear that judges actually are rejecting present in favor of past uses, even when they talk as though they are. It would probably have been stretching even the present meaning of the word "State," for instance, to call the District of Columbia a "State," (even though it does perform many state functions, such as collecting local income taxes, registering automobiles, providing a legal domicile). In this sense, the present meaning may be very close to the 1787 meaning, which $\mathrm{Mr}$. Justice Jackson described as "those concrete organized societies which were thereby contributing to the federation ...."52 In our everyday

48 Jackson, Full Faith and Credit-The Lawyer's Clause of the Constitution, 45 Colum. L. Rev. I, 6 (1945).

49 "The constitution contains no description of those processes which it was intended to allow or forbid .... To what principles, then, are we to resort to ascertain whether this process, enacted by congress, is due process? To this the answer must be two-fold. We must examine the constitution itself, to see whether this process be in conflict with any of its provisions. If not found to be so, we must look to those settled usages and modes of proceeding existing in the common and statute law of England, before the emigration of our ancestors, and which are shown not to have been unsuited to their civil and political conditions by having been acted on by them after the settlement of this country." Den ex dem. Murray v. Hoboken Land \& Improv. Co., 59 U.S. (18 How.) 272, 276-77 (1855) (Curtis, J.).

50 E.g., Bartkus v. Illinois, 359 U.S. 121, 124-26 (1959) (refusing to apply double jeopardy).

51 "If the idea of a document of superior legal authority is to have meaning, terms which have a precise, history-filled content to those who draft and adopt the document must be held to that precise meaning." Hurst, The Role of History, in Supreme CourT AND SURREME LAW 57 (Cahn ed. 1954). Hurst's analysis suggests that these precise words "involve the definition of particular legal agencies or particular legal procedures," not "grants" of power or "standards" of conduct. Ibid.

52 National Mut. Ins. Co. v. Tidewater Transfer Co., 397 U.S. 582, 588 (1949) (for himself, Black and Burton, JJ.). These three held that Congress could use its article I power over the District of Columbia to enlarge the jurisdiction of article III federal courts, and with Rutledge and Murphy, who held that the word "state" could be expanded, constituted the majority of five. As Mr. Justice Frankfurter said, "conflicting minorities in combination bring to pass a result-paradoxical as it may appear-which differing majorities of the Court find insupportable." $Y d$. at 655. 
language, the particular word "State" seems to be somewhat frozen to the concrete; a "State" can almost be pointed to, in that primitive notion of how best to define a word. Thus it may be not the judge so much as our language which freezes some words.

The notion that present-not past-meanings may really be the controlling force upon the judge is reinforced by recalling that some words which probably did have a "precise" content in 1787 (in the sense that they, too, almost stood for objects) have been permitted to expand in their legal uses as they have expanded in their non-legal uses. Thus, while "person," "property" and "commerce" were probably considered quite concrete and tangible in 1787 , as our economic and social relationships have become more complicated, those concepts have been put to more abstract and less tangible uses. These changed uses in the non-legal world have impinged upon, and eventually been accepted by, the legal world. ${ }^{53}$ In this sense, these words are "key" not because judges have expanded them, but because our language has. Even the Dred Scott Court, although speaking in terms of discovering a past use, ${ }^{54}$ was reflecting a use then current in at least the Southern states. The difference between a past use and a present one is far from clear, and judges who think they are discovering the former may well be simply reflecting the latter.

The choice between a past and a present use seems peculiarly clear when courts deal with words which have few uses outside the courtroom itself. Thus "bill of attainder" and "habeas corpus" have meanings which it is a court's function to elucidate, with virtually no pressure from meanings in the non-legal world. But for a court to consider such legal concepts to have had a "frozen" meaning merely because there is no non-legal pressure for change is to misconceive the nature of the judicial

53 In extending "commerce" to include interstate telegraph lines, for instance, the Court said: "The powers thus granted are not confined to the instrumentalities of commerce ... known or in use when the Constitution was adopted, but they keep pace with the progress of the country, and adapt themselves to the new developments of time and circumstance. They extend from the horse with its rider to the stage-coach, from the sailing-vessel to the steamboat . . . and from the railroad to the telegraph, as these new agencies are successively brought into use to meet the demands of increasing population and wealth." Pensacola Tel. Co. v. Western Union Tel, Co., 96 U.S. 1, 9 (1877).

54 "The general words above quoted would seem to embrace the whole human family, and if they were used in a similar instrument at this day would be so understood." Dred Scott v. Sandford, 60 U.S. (19 How.) 393, 410 (1857). "No one, we presume, supposes that any change in public opinion or feeling, in relation to this unfortunate race, in the civilized nations of Europe or in this country, should induce the court to give to the words of the Constitution a more liberal construction in their favor than they were intended to bear when the instrument was framed and adopted. Such an argument would be altogether inadmissible in any tribunal called on to interpret it." Id. at 426. 
process itself. The development of the writ of habeas corpus stretched over centuries preceding the insertion of the term in the Constitution. Why should the growth of that remedy be considered to have been suddenly and finally completed in 1787?55 To look upon habeas corpus as a frozen concept is almost to commit the fallacy of thinking that words are names for things. Words do not stand for anything; they are tools. As legal tools, "habeas corpus" and "bill of attainder" are peculiarly within the judge's province to use, and therefore peculiarly within his duty to develop.

And surely the judicial development of words widely used outside the law is as proper as the development of words peculiarly legal: In either case, a use is not a constitutional use until the Supreme Court says it is. The changed use may seem less drastic in the case of a word like "commerce," where it appears that the judge is merely responding to external pressure. But if the judge were merely responding, he would be abdicating his judicial responsibility just as much as he does when he "freezes" a particular legal concept. In both situations, the judge should make a choice rather than give a response. And the choice must be centered upon the appropriate current use for the word.

It is misleading, however, to think of this choice as one in which words are given either "frozen" or "dynamic" meanings. Such a dichotomy suggests that words, while not being names for things, are themselves things which have both size and life. Holmes was fond of this biological model for words. Speaking of constitutional words as "organic, living institutions" whose "significance is vital, not formal," Holmes said that their meanings could not be found in a dictionary, but rather by considering "their origin and the line of their growth." 56 Such a model suggests that a word has a core or nucleus from which future uses grow. From this suggestion it is an easy step-although not one which Holmes himself took-to the notion that at least that solid core as it existed in

55 "I think some of the provisions [of the Constitution] have a deceptively precise historic meaning which should not mislead the courts. I think this is particularly true of the guarantee of the privilege of the writ of habeas corpus. The Supreme Court has a tendency throughout to regard habeas corpus as that form of remedy which was known in 1787 on the basis of a congeries of English statutes, practices, and traditions. My point is that there is involved in such institutions or practices a dynamic element which itself was adopted by the framers. ... [T] he whole history of habeas corpus shows that the courts in England were capable of developing the writ, and we did not adopt an institution frozen as of that date." Freund, Discussion of Address by William Hurst, The Process of Constitutional Construction, in SUPREME COURT AND Surreme LAw 55, 61 (Cohn ed. 1954). See also Fay v. Noia, 372 U.S. 391 (1963).

56 Gompers v. United States, 233 U.S. 604, 610 (1914) (holding that contempt of court could be an "offense" for purposes of the statute of limitations even though contempt is not a "crime" for purposes of the right to a jury trial). 
1787 binds the future. Thus it is sometimes said that words can "grow" and "expand," but cannot contract. 57

One problem with such a notion is that the size of the "original core" may be as much a matter for debate as the question of whether the word itself is "big" or "little." Was the core of a bill of attainder legislative action inflicting such harm as the loss of salary upon a particular individual, as Mr. Justice Black thought; or was the core legislative action determining the guilt of a particular person, as Mr. Justice Frankfurter thought? ${ }^{58}$ Was the core of the privilege against self-incrimination the protection of witnesses from being coerced into helping to convict themselves, in which case immunity from prosecution displaces the danger, as Mr. Justice Frankfurter thought; or was the core the protection of witnesses from public ridicule and disgrace, in which case only a "right of silence" will suffice?59 These are questions which history does not answer; the evidence can properly be interpreted in either way. Indeed, such a debate over a past core is really a debate over present application. The evidence of the past merely masks the arguments of the present, just as it does in debates over whether a word is "big" or "small."

A more important problem lurking in the "core meaning" idea is the assumption that at the center of meaning there is solid stuff which is more durable than mere current uses. It is probably this assumption which led the Court to say that "while the meaning of constitutional guaranties never varies, the scope of their application must expand or contract to meet the new and different conditions which are constantly coming within the field of their operation. ... [A] degree of elasticity is thus imparted, not to the meaning, but to the application of constitutional principles ...." 60 Meaning is application. The Court's italicized distinction reflects an illusory hope for both fixity of meaning and flexibility of application. Words are put to new uses and are made to discard old ones, but not by any process as regular as growth. Certainly a past use should not be made to appear more solid than a present use simply by calling it a core.

57 But cf. "It is rational, fair, and logical to say that you want a rigid historical interpretation of the first amendment as to its minimum meaning but you also want some expansions to go on in other situations? If you can have the expansions, then why can't you likewise have contractions in order to meet current situations?' Frank, Discussion of Address by William Hurst, op. cit supra note 55, at 64 .

58 See United States v. Lovett, 328 U.S. 303 (1946) (Black, J., for the Court; Frankfurter, J, dissenting).

59 See Ullman v. United States, 350 U.S. 422 (1956) (Frankfurter, J., for the Court; Black and Douglas, JJ., dissenting).

60 Village of Euclid v. Ambler Realty Co., 272 U.S. 365, 387 (1926) (Sutherland, J.) (holding reasonable zoning ordinances within the local police power and not a violation of due process). 
The idea that there is a solid core of meaning really assumes that for each word, there is a single meaning. Indeed, the Court's very focus upon meaning can have a stultifying effect upon sensible interpretation because of the persistence of the one-word, one-meaning fallacy. A meaning for the purposes of one case tends to become the meaning for all purposes. In holding that the constitutional procedure requiring that proposed amendments be ratified by state legislatures precluded the submission of such amendments to a popular referendum, the Court declared:

The only question really for determination is: What did the framers of the Constitution mean in requiring ratification by "Legislatures"? That was not a term of uncertain meaning when incorporated into the Constitution. What it meant when adopted it still means for the purpose of interpretation. A Legislature was then the representative body which made the laws of the people. ${ }^{61}$

When the Court was later presented with the question of whether a state governor could veto an act reapportioning congressional legislative districts under article I, section 4, it was confronted with its prior language about meaning. Mr. Chief Justice Hughes, for a unanimous Court, upheld the propriety of a veto, stating: "Much that is urged in argument with regard to the meaning of the term 'Legislature' is beside the point." The Chief Justice then quoted the above language about the "Legislature" being "the representative body which made the laws," and continued: "The question here is not with respect to the 'body' as thus described but as to the function to be performed. The use in the Federal Constitution of the same term in different relations does not always imply the performance of the same function." The "function" in reapportioning was "lawmaking in its essential features," he said, as distinguished from "ratifying"; and for lawmaking, a veto was proper, while for ratifying, a referendum was not. ${ }^{62}$ Hughes was speaking in terms of applications of the word; his task would have been simpler had the prior Court not spoken in terms of a single prior meaning.

The language of meaning may create even greater difficulties when the same word in the same section is important to a subsequent case. Could a defendant in a criminal prosecution, for instance, be convicted by a jury of eleven men after he had specifically waived any objection to proceeding with the trial after the twelfth juror had withdrawn because of illness? An earlier case had declared that "the jury referred to in the

61 Hawke v. Smith, No. 1, 253 U.S. 221, 227 (1920).

62 Smiley v. Holm, 285 U.S. 355, 365-67 (1932). The Chief Justice's task was eased by the fact that in 1787, two states provided for executive veto of legislative bills, and he thus used historical evidence to melt a frozen meaning. $I d$. at 368 . 
original Constitution and in the sixth amendment is a jury constituted, as it was at common law, of twelve persons, neither more nor less." 63 That holding had been elucidated in terms of the meaning of the word "jury": "It must ... be taken that the word 'jury' and the words 'trial by jury' were placed in the Constitution of the United States with reference to the meaning affixed to them in the law as it was in this country and in England at the time of the adoption of that instrument . . . " That fixed meaning required "a jury composed of not less than twelve persons." ${ }^{4}$ When the question of the eleven-man jury arose, the Court was therefore forced to state: "A constitutional jury means twelve men as though that number had been specifically named; and it follows that when reduced to eleven it ceases to be such a jury quite as effectively as though the number had been reduced to a single person." 65 The Court therefore viewed the question as whether trial by jury was, on the one hand, "a part of the structure of government" 68 (and thus something calling for a kind of ostensive definition), or, on the other hand, a right which could be waived and qualified by the accused. The Court concluded that it was a right, and one which could be waived. ${ }^{67}$ Still, at least as the Court saw the result, trial by eleven men sitting in the jury box was valid because trial by jury included a right to proceed without a "jury."

Let us assume, however, that care in the Court's choice of language could prevent future courts from having to act as if there were a single meaning for each constitutional word. Assume, further, that the Court does not act as if there were a solid core for each word. We are left with the basic question: Do past meanings bind the present? Yet the question has virtually answered itself. If, as we said at the outset of this discussion, the meaning of a word is its use, and if its use can never be found apart from its context, then we need only add that an inseparable constituent of context is the time at which the use occurs to show that a past meaning cannot bind the present. It is precisely the time element of the context of use which is "the past." A past use, is locked to a past time, and as such does not bind the present unless the present chooses to be so bound. What Mr. Justice Holmes said in regard to statutes is even truer in regard to the Constitution: "We do not inquire what the legislature meant; we ask only what the statute means." 68

63 Thompson v. Utah, 170 U.S. 343, 349 (1898) (Harlan, J.).

64 Id. at 350.

65 Patton v. United States, 281 U.S. 276, 292 (1930) (Sutherland, J.). (Emphasis added.). 66 Id. at 296.

67 Id. at 306-07.

68 Holmes, Collected Legal Papers 207 (1920). 


\section{III. - The Search for Purpose}

In holding that the equal protection clause of the fourteenth amendment did not apply to a situation where a state had created an economic monopoly with which certain people were virtually forced to deal, the Supreme Court, through Mr. Justice Miller, declared:

In the light of the history of these amendments [the thirteenth and fourteenth], and the pervading purpose of them, . . . it is not difficult to give a meaning to this clause. The existence of laws in the States where the newly emancipated negroes resided, which discriminated with gross injustice and hardship against them as a class, was the evil to be remedied by this clause, and by it such laws are forbidden. ... We doubt very much whether any action of a State not directed by way of discrimination against the negroes as a class, or on account of their race, will ever be held to come within the purview of this provision. ${ }^{69}$

This is a classic statement of the idea that the purpose for which a constitutional provision was enacted limits the future use of that provision. Our question is whether such a past purpose does properly limit the later applications of the provision.

What do we mean by purpose? Blackstone's rules for the interpretation of statutes said that the last but "the most universal and effectual way of discovering the true meaning of a law, when the words are dubious, is by considering the reason and spirit of it; or the cause which moved the legislator to enact it."70 That cause is what we mean by purpose. How do we discover that cause? One rule long ago laid down in England was to compare the state of the law before the statute with the changes which the law created, in order to discover "the mischief and defect" for which the prior law did not provide. The judicial task was to construe the statute in a manner designed to "suppress the mischief, and advance the remedy, and to suppress subtle inventions and evasions for continuance of the mischief." "71

One difficulty in applying these English principles to the American Constitution is that, except for the amendments (some of which, like the eleventh, may well have been specific responses to prior case law), there is no prior law with which to compare the constitutional "remedy." All that we have for the comparison are prior states of fact running back through the whole colonial period-the grievances. which led to the Revolution-as well as through the period when the Articles of Con-

69 Slaughter-House Cases, 83 U.S. (16 Wall.) 36, 81 (1873).

70 I Blackstone, Commentaries 61 (8th ed. 1778).

71 Heydon's Case, 3 Co. Rep. 7a, 7b, 76 Eng. Rep. 637, 638 (Ex. 1584). See Keeton, Legal History in Modern English Decisions, 2 How. L.J. I (1956). 
federation were the governing law. Thus when the Supreme Court searches for the purpose of a particular constitutional provision, the scope of its search is necessarily wider than that of a court in the common-law tradition, where the interplay of case law and statutory law may demonstrate the purpose for all to see. A constitutional purpose is much harder to discover. ${ }^{72}$

It is not surprising, therefore, that history presents most constitutional purposes in an ambiguous light. Was the purpose of the establishment clause to suppress the evils of a state religion, or was it to suppress the evils of a religious state? The language will support either interpretation, and the history of the times does not provide a clear answer. ${ }^{73}$ And was the purpose of the equal protection clause really limited, as Mr. Justice Miller thought, to the protection of newly emancipated slaves? $\mathrm{Mr}$. Justice Bradley thought it was much broader, focused instead upon the relations between state and nation: "The mischief to be remedied was not merely slavery and its incidents and consequences; but that spirit of insubordination and disloyalty to the National government which had troubled the country for so many years in some of the States ...."74 And even the thirteenth amendment, presumably directed at slavery itself, was said by one Justice to have a purpose broad enough to protect, under the phrase "involuntary servitude," seamen cast into prison for breaking their contracts after embarkation, ${ }^{75}$ although the majority of the Court interpreted the historical evidence more narrowly.

Aside from such ambiguities lurking in the historical evidence, two further points-one made in connection with intent, the other in connection with meaning-must be restated here. The first is that, even if the purpose appears free from ambiguity, the function of the Court is usually to resolve the conflicting purposes of different constitutional provisions and not simply to discover the purpose of one provision. The second is that we should be wary of the assumption that each provision

72 Note, for instance, the breadth of the Court's search for the purpose of the establishment clause of the first amendment: "These words of the first amendment reflected in the minds of early Americans a vivid mental picture of conditions and practices which they fervently wished to stamp out in order to preserve liberty for themselves and for their posterity." Present-day Americans, the Court went on, tend to forget "the evils, fears, and political problems that caused that expression to be written into our Bill of Rights. ... Once again, therefore, it is not inappropriate briefly to review the background and environment of the period in which that constitutional language was fashioned and adopted." Everson v. Board of Educ., 330 U.S. I, 8 (1947) (Black, J).

73 Compare Frankfurter, J., concurring, with Reed, J., dissenting in Illinois ex rel. McCollum v. Board of Educ., 333 U.S. 203 (1948).

74 Slaughter-House Cases, 83 U.S. (16 Wall.) 36, 123 (1873).

76 Robertson v. Baldwin, 165 U.S. 275 (1897) (Harlan, J., dissenting). 
had only a single purpose, just as we should be alert to the one wordone meaning fallacy.

A clearly discernible purpose of a constitutional provision may well be relied upon to include within the scope of the provision a situation which the words do not seem to cover, or to exclude a situation which the words appear to cover. Thus in construing the right to choose representatives as encompassing state primary elections, the Court turned "to the words of the Constitution read in their historical setting as revealing the purpose of its framers, and in search for admissible meanings of its words which, in the circumstances of their application, will effectuate those purposes."76 A dominant purpose, the Court continued, was the right of the people to choose representatives by some form of election, and here the primary was "an integral part of the procedure of choice." Since primaries had not existed in 1787, the Court felt bound to state: "There is no historical warrant for supposing that the framers were under the illusion that the method of effecting the choice of the electors would never change . . . ."7t Here the Court did not feel bound or constricted by the past purpose; quite the contrary, it utilized that past purpose to bolster a result justified by the present.

Similarly, a past purpose may be used to narrow the application of constitutional words. Mr. Justice Brennan declared, for instance, that the "speech" protected by the first amendment might be limited to speech concerned with political and social matters, on the theory that a dominant purpose was to protect the vitality of debates concerned with the processes of government. ${ }^{78}$ But regardless of whether the past purpose is used to broaden or to narrow the scope of the provision, such a broadening or narrowing is not compelled by the past. Past purposes should be used for present purposes.

The primary reason for treating such past purposes with less respect in dealing with the Constitution than in dealing with statutes is that the framers and ratifiers of the Constitution, unlike legislators, were trying to do more than meet existing problems. They were trying to look into the future as well, and to provide a framework in which that future could deal with its own problems. In this sense, the purposes of the Constitutional Convention were truly high purposes, growing out of, but going beyond the remedying of particular evils. Mr. Chief Justice Stone, speaking for the Court after the death of Mr. Justice Brandeis, said that

76 United States v. Classic, 313 U.S. 299, 317-18 (1941) (Stone, J.).

77 Id. at 318.

78 Roth v. United States, 354 U.S. 476, 482-85 (1957) (holding obscenity not protected by the first amendment). 
Brandeis never lost sight of the fact that a Constitution "is primarily a great charter of government .... Hence, its provisions were to be read not with the narrow literalism of a municipal code or a penal statute, but so that its high purposes should illumine every sentence and phrase of the document and be given effect as a part of a harmonious framework of government."79

Perhaps the highest purpose was to achieve a delicate balance between remedying evils which were then vivid while speaking with a degree of generality which would permit the future to remedy its own evils without having frequently to amend the document. As Mr. Justice Stone made the point in the Classic case:

We may assume that the framers of the Constitution in adopting that section, did not have specifically in mind the selection and elimination of candidates for Congress by the direct primary any more than they contemplated the application of the commerce clause to interstate telephone, telegraph and wireless communication, which are concededly within it. But in determining whether a provision of the Constitution applies to a new subject matter, it is of little significance that it is one with which the framers were not familiar. For in setting up an enduring framework of government they undertook to carry out for the indefinite future and in all the vicissitudes of the changing affairs of men, those fundamental purposes which the instrument itself discloses. Hence we read its words, not as we read legislative codes which are subject to continuous revision with the changing course of events, but as the revelation of the great purposes which were intended to be achieved by the Constitution as a continuing instrument of government. 80

The essential point is that statutes, as the Court noted, are "subject to continuous revision" as events change, but a constitution is designed with the high and great purpose of "enduring" as a "continuing instrument of government." In order for the constitutional framework to so endure, past purposes-like past intents and past meanings-should never be permitted to bind the present except as those purposes, intents and meanings are reflected in the words of the document. As Mr. Chief Justice Marshall put it: "[A]lthough the spirit of an instrument, especially of a constitution, is to be respected not less than its letter, yet the spirit is to be collected chiefly from its words." 81

79317 U.S. xlii, xlvii (1942). (Emphasis added.).

80 United States v. Classic, 313 U.S. 299, 315-16 (1941). (Emphasis added.).

81 Sturges v. Crowninshield, 17 U.S. (4 Wheat.) 122, 202 (1819). 


\section{Conclusion: The Outlines of a Valid Approach}

Admittedly, the emphasis of this essay has been destructive: Its purpose has been to free the present from the strictures of the past. One reason for attempting to question certain judicial uses of history is a tactical one; when judges speak in terms of searching for something binding, the results of that search are subject to correction by better historians. Mr. Justice Holmes, with Mr. Justice Brandeis, declared that the English law on seditious libel had, in effect, been repealed by the first amendment, ${ }^{82}$ and this historical interpretation was later adopted by the Court; 83 but 'the Justices' historical conclusions now seem to have been overstated.84 Similarly, Mr. Justice Black declared that one of the purposes of the fourteenth amendment was to make the Bill of Rights applicable to the states, $^{85}$ but that historical explanation is now highly questionable. ${ }^{86}$ Somehow there is an implication that such historical correction discredits the position of the judge, even though the judge's position might have been, and usually was, supported more by considerations of the present than of the past. Because, as Mr. Justice Jackson said, "judges often are not thorough or objective historians," 87 judges should avoid the language of the historian. Historical correction is usually beside the point, but it is made to seem relevant by loose judicial talk about a search for past intent, past meaning or past purpose. ${ }^{87 a}$

82 "I wholly disagree with the argument of the Government that the first amendment left the common law as to seditious libel in force. History seems to me against the notion." Abrams v. United States, 250 U.S. 616, 630 (1919) (dissenting opinion).

83 " $[\mathrm{T}] \mathrm{o}$ assume that English common law in this field became ours is to deny the generally accepted historical belief that 'one of the objects of the Revolution was to get rid of the English common law on liberty of speech and of the press." Bridges v. California, 314 U.S. 252, 264 (1941) (Black, J.).

84 See Levy, Legacy of Suppression: frefdom of Speech and Press in Early AMERICAN History (1960).

85 "My study of the historical events that culminated in the fourteenth amendment and the expressions of those who sponsored and favored, as well as those who opposed its submission and passage, persuades me that one of the chief objects that the provision of the amendment's first section, separately, and as a whole, were intended to accomplish was to make the Bill of Rights, applicable to the states. . . . This historical purpose has never received full consideration or exposition in any opinion of this Court interpreting the amendment." Adamson v. California, 332 U.S. 46, 71-72 (1947) (dissenting opinion). Mr. Justice Black sets forth this history in an appendix to his dissent. Id. at 92.

86 See Fairman and Morrison, Does the Fourteenth Amendment Incorporate the Bill of Rights?, 2 STAN. L. REv. 5 (1949).

87 Jackson, supra note 48 , at 6 .

87a But cf.: "In those situations where law is frankly based on history of the past, should the law change as research adds to the store of historical knowledge and alters views previously held?

"In the United States we early answered that question in the affirmative. While 
A second reason for attempting to free the present from the binding force of history goes beyond the tactical advice that judges should choose their words with care. History must be stripped of its binding force so that it may be used properly; for, although such proper uses are not unconnected with the improper uses we have been discussing, the proper uses of history are both less restricting and more illuminating than the search for a controlling past.

First, even though we should not search for a binding past intent, we may look for persuasive past insights. It seems eminently appropriate, for instance, to consult statements of Marshall on the scope of the federal judiciary, or of Jefferson and Madison on the first amendment, because these men had thought about the problems; their fears, hopes and conclusions can assist us today because the problems of today are frequently not unlike the problems of yesterday. Their insights are not controlling upon us, but they can help us in our own deliberations.

Second, even though we should not search for the past meaning, we may look for various past meanings in exploring the linguistic possibilities of the provision under discussion. The Court should carefully note past uses-whether in the Philadephia proceedings, in the prevailing customs of the times or in other documents-to avoid too easily concluding that the present common use for a word or phrase is the only possible use. Thus changes in the wording of a provision in the course of debate may be as revealing in constitutional as in statutory interpretation. ${ }^{88}$ Past common uses of words are also relevant. The fact, for instance, that the words "exceptions" and "regulations" seem to have had fairly narrow uses before being employed in article III to define congressional power over the appellate jurisdiction of the Supreme Court may someday

Marshall was still Chief Justice, in 1819, our Supreme Court was called on to determine the validity of a testamentary charity under the laws of a State that had expressly repealed the statute of 43 Elizabeth I. It was held that, as a matter of common law, the bequest could not be sustained. [Baptist Ass'n v. Hart's Executors, 17 U.S. (4 Wheat.) 1 (1819).] Thereafter, your [British] Record Commission published the Calendars of the Proceedings in Chancery in the Reign of Queen Elizabeth [in 1827], and when the same issue once more arose, in the Girard College case in 1844 [Vidal v. Girard's Executors, 43 U.S. (2 How.) 12 (1844)], a different result was reached. Mr. Justice Story said, 'Whatever doubts, therefore, might properly be entertained upon the subject when the [earlier case] was before this court, those doubts are entirely removed by the late and more satisfactory sources of information to which we have alluded'. [43 U.S. (2 How.) at 196.] And Webster, who was losing counsel in the later litigation, had said right after the argument that his opponent "has buried me under those three big folios'. [Wallace, The Reporters (Heard's 4th ed. 1882), p. 463.]" WIENER, UsEs and Abuses of Legal History: A Practitioner's View 28 (Selden Society Lecture, London, 1962). (Footnotes omitted or bracketed.)

88 See, e.g., Erie R.R. v. Tompkins, 304 U.S. 64, 72-73 (1938), where Mr. Justice Brandeis put to use the research of Charles Warren, New Light on the History of the Federal Judiciary Act of 1789,37 HaRv. L. REv. 49 (1923). 
assist the Court in holding that such power does not mean that Congress may completely abolish such jurisdiction. ${ }^{80}$ Similarly, the wording of other documents may help. Madison's Remonstrance, and the Virginia Bill for Establishing Religious Freedom, for instance, may suggest possible applications of the terse language of the first amendment which the words alone might not bring to mind.90 The essential point is not that these past uses are in any way binding, but rather that they have an important role in freeing the modern judge from unnecessary strictures of language. A past use may or may not be adopted-but it should be known, and if it is adopted, it should be for the reasons of today. ${ }^{91}$ In this sense, history can help in the Court's search for "admissible meanings" 92 of constitutional words.

Third, even though we should not search for a binding past purpose, we may look for past evils, changes, developments and trends-all as aids in understanding the present. As Lincoln said, "If we could first know where we are, and whither we are tending, we could better judge what to do, and how to do it." 93 It is perhaps in this sense-that the present has been -shaped by the past and can only fully be understood through knowledge of that past-that Holmes' rather cryptic statement should be interpreted: "The present has a right to govern itself, so far as it can. . . . Historical continuity with the past is not a duty, it is only a necessity." 94

A knowledge of such historical continuity is essential if a modern judge is to make an enlightened decision. But a search for such knowledge is really a search for changes over time, rather than for a purpose at a moment in time. The particular institution involved in each case should be fully understood in terms of its origin, development and present function in society. As Holmes said, in construing the tenth amendment's scope: "The case before us must be considered in the light of our whole experience and not merely in that of what was a hundred years ago. . . .

89 See Ratner, Congressional Power over the Appellate Jurisdiction of the Supreme Court, 109 U. PA. L. REv. 157, 168-71 (1960).

90 See Rutledge, J., dissenting in Everson v. Board of Educ., 330 U.S. I (1947).

$91 \mathrm{Mr}$. Chief Justice Marshall used history "to illuminate a point he had already made through some other fashion, or to make more cogent an argument already presented.... History was a handmaiden of the law, not a despotic mistress." Klinkhamer, John Marshall's Use of History, 6 CATHOx\C U.I. REv. 78, 87-88 (1956). And see Klinkhamer, The Use of History in the Supreme Court, 1789-1835, 36 U. DET. L.J. 553 (1959).

92 United States v. Classic, 313 U.S. 299, 317 (1941). History can help in this search just as can "maxims of construction." Such maxims "simply answer the question whether a particular meaning is linguistically permissible, if the context warrants it." Hart \& SAcks, The Legal Process 1220-22 (tent. ed. 1958).

93 The "House-Divided" Speech at Springfield, Ill., June 16, 1858, in Abraham LincolN: His SpeEches ANd WrITINGS 372 (Basler ed. 1946).

94 Holmes, Collected Essays 191. 
We must consider what this country has become in deciding what that amendment has reserved."

Such an inquiry, of course, is vast-but it is necessary. It was thus proper for the Court in deciding whether racially segregated schools violated the equal protection clause to examine closely the function of public education, not only at the time the fourteenth amendment was enacted, but as it has developed over the years.96 Similarly, when the Court came to decide whether a state could force work to cease on Sundays without violating the establishment or free exercise clauses, it was proper-as Mr. Justice Frankfurter did-to consult sources dealing with primitive rituals, Greek tragedy, modern Indian customs, the early relations between religion and capitalism and the attempts of another country, Britain, to deal with the problem. ${ }^{97}$ By such an expansive inquiry into history as a process, a day-of-rest was justified as constitutionally permissible in modern society despite that day's religious

95 Missouri v. Holland, 252 U.S. 416, 433-34 (1920).

98 Brown v. Board of Educ., 347 U.S. 483, 489-90 (1954): "An additional reason for the inconclusive nature of the [fourteenth] amendment's history, with respect to segregated schools, is the status of public education at that time. In the South, the movement toward free common schools, supported by general taxation, had not yet taken hold. Education of white children was largely in the hands of private groups. Education of Negroes was almost non-existent, and practically all of the race were illiterate. In fact, any education of Negroes was forbidden by law in some states. Today, in contrast, many Negroes have achieved outstanding success in the arts and sciences as well as in the business and professional world. It is true that public school education at the time of the amendment had advanced further in the North, but the effect of the amendment on Northern States was generally ignored in the congressional debates. Even in the North, the conditions of public education did not approximate those existing today. The curriculum was usually rudimentary; ungraded schools were common in rural areas; the school term was but three months a year in many states; and compulsory school attendance was virtually unknown. As a consequence, it is not surprising that there should be so little in the history of the fourteenth amendment relating to its intended effect on public education."

The Court stated further: "We must consider public education in the light of its full development and its present place in American life throughout the Nation. Only in this way can it be determined if segregation in public schools deprives these plaintiffs of the equal protection of the laws.

"Today, education is perhaps the most important function of state and local governments. Compulsory school attendance laws and the great expenditures for education both demonstrate our recognition of the importance of education to our democratic society. It is required in the performance of our most basic public responsibilities, even service in the armed forces. It is the very foundation of good citizenship. Today it is a principal instrument in awakening the child to cultural values, in preparing him for later professional training, and in helping him to adjust normally to his environment. In these days, it is doubtful that any child may reasonably be expected to succeed in life if he is denied the opportunity of an education. Such an opportunity, where the state has undertaken to provide it, is a right which must be made available to all on equal terms." Id. at 492-93.

97 Frankfurter, J., concurring, in McGowan v. Maryland, 366 U.S. 420, 470-83, 504 n.92 (1961). 
origins. ${ }^{98}$ History can thus be used to make the Court aware of the subtleties and complexities of the problem before it. Used in this way, history, as Judge Wyzanski has said, is "another perspective or value against which to measure law." 99

The nature of this "perspective," however, must be clearly understood if we are not to reinstate history as the very monarch which it has been the purpose of this essay to dethrone. One of the basic impulses behind turning to history for a controlling answer to a question of current interpretation has been to find a way to keep judges from deciding cases according to personal whim, personal preference, individual judgment or the passion of the day. ${ }^{100}$ But to phrase the impulse in this way presents a false dichotomy. The choice is not between the judgment of the individual and the judgment of history: History makes no judgments; only individuals do. History should be merely one aid in helping that individual come to a sensible_but necessarily personal-judgment.

History thus provides enlightenment. Indeed, the Court frequently says that it reads the provisions of the Constitution "in the light of" history.101 The image of light suggests most clearly how history should be used. It

98 The result of such an inquiry may well lead the judge to view the historical evidence as a kind of hurdle-not something binding, but something which only a strong modern justification can overcome. "If a thing has been practised for two hundred years by common consent, it will need a strong case for the fourteenth amendment to affect it . . . ." Holmes, J., in Jackman v. Rosenbaum Co., 260 U.S. 22,31 (1922) (holding a state statute providing for damages to owners of a party wall only upon proof of negligence not violative of due process). The same view may be stated in terms of a "policy of clear statement": "In this condition of the law in respect to suffrage in the several States it cannot for a moment be doubted that if it had been intended to make all citizens of the United States voters, the framers of the Constitution would not have left it to implication. So imporant a change in the condition of citizenship as it actually existed, if intended, would have been expressly declared." Minor v. Happersett, 88 U.S. (21 Wall.) 162, 173 (1874) (holding that the definition of citizenship in the fourteenth amendment did not impliedly grant women the right to vote). Aside from the language of intent here, the Court was really using historical evidence as a kind of presumption against change when neither the language of the Constitution nor the current conditions of society justified such a change.

99 Wyzanski, History and Law, 26 U. CHI. L. Rev. 237, 244 (1959).

100 "Is the law in our times nothing but a choice of policy made in the open ring under the watchful eye of a fair boxing referee? ... We seek a measuring rod-an appraisal scale-a standard not semper ubique but good for more than this day and place." $I d$. at 242. See also notes 33 and 40 supra.

101 E.g., Wesberry v. Sanders, 376 U.S. 1, 17 (1964) (Black, J.) (holding unconstitutional Georgia statute apportioning congressional districts as violating the requirement implicit in Art. I, § 2's use of the phrase "chosen by the people" that, as neariy as practicable, one person's vote in a congressional election is to be worth as much as another's); Hamilton v. Regents of Univ. of Cal., 293 U.S. 245, 266 (1934) (Cardozo, J.) (holding constitutional, over religious objections, the power of a state to require those who voluntarily attend state university to submit to military training). 
is neither prologue on the one hand, nor director of the drama on the other; rather, history is a spotlight, always available to illumine, but not to blind. History does not provide the answers to the problems of today; it merely helps to frame the questions. 